\title{
WHAT GENERAL COMPETENCIES ARE REQUIRED FROM THE CZECH LABOUR FORCE?
}

\author{
Jiří Balcar, Lenka Janíčková, Lenka Filipová*
}

\begin{abstract}
:
Knowledge of employers' requirements on competencies of job applicants is highly important in the process of human capital accumulation. This paper focuses on the general competencies since they can be applied in a wide range of jobs or tasks and increase an individual's employability. First, employers' requirements on general competencies are identified and described on the basis of 3,822 job advertisements published online. Second, the econometric analysis is used in order to test hypothesis whether examined demand for general competencies is really general or if it differs significantly with respect to required education and firm characteristics. The results of our probit regressions proved that the requirements on examined general skills significantly differ according to the education required and some categories of NACE and ownership of the firms.
\end{abstract}

Keywords: General competencies, soft competencies, job advertisements, probit model.

JEL Classification: J23, J24

\section{Introduction}

The match of individuals' human capital accumulated through education, on-the-job training, information gathering, investing in health, investments in personal virtues, etc. (Becker, 1993; Schultz, 1961), with job requirements determines his/her ability to act adequately (Belz, Siegrist 2001), i.e. competency for job performance (it can be emphasized that a competency for job performance consists in a great number of more specific competencies needed to perform particular job tasks). Knowledge of employers' requirements on competencies of job applicants is thus highly important in the process of human capital accumulation.

The paper describes demand for general (i.e. broadly applicable) competencies on the Czech labour market. It is elaborated in two steps. First, employers' requirements on general competencies are identified and described on the basis of the content analysis of job advertisements published online. Second, the econometric analysis is used in

* VŠB-Technical University of Ostrava, Sokolská tř́ida 33, 70121 Ostrava (balcar.er@gmail.com). Authors would like to thank to Jaromír Gottvald, Milan Šimek, Markéta Škutová and Monika Mrlinová for their valuable comments. They also gratefully acknowledge effort of students of Economic faculty of VŠB-Technical university of Ostrava, who collected job advertisements and coded all records into the database.

This paper has been funded by a grant from the Czech Science Foundation (grant number P402/11/2464) for a research on the gender wage gap in the Czech Republic.

It was supported also by the European Social Fund within a project No. CZ.1.07/2.3.00/20.0296. 
order to test hypothesis whether examined demand for general competencies is really general or if it differs significantly in dependence on required education and firm characteristics, such as NACE and ownership.

Section 1 of the paper defines general competencies discussed in the paper. Section 2 briefly reviews empirical evidence on general competencies in the Czech Republic. Section 3 discusses our data and methodology. Section 4 brings the results of descriptive analysis of general competencies required on the Czech labour market. Section 5 presents the results of probit regression analysis testing the hypothesis of competencies generality.

\section{General Competencies}

There are many different approaches to defining "competencies" (e.g. Spencer, Spencer, 2008; European Commission, 2008; European Commission, 2007; Kessler, 2006; Kessler, Strasbourg, 2005; Cripe, Mansfield, 2002; CEDEFOP, 2002; Woodruffe, 1992). These definitions enriched by the inborn differences, which also have significant influence on an individual's work performance, lead to defining competencies as a set of inborn or acquired personal characteristics, attitudes, knowledge and skills leading to high-quality performance (Balcar, Homolová, Karásek, et al., 2011).

It is possible to distinguish between general and specific competencies according to their applicability on the labour market. General competencies can be defined as a set of competencies that can be applied to any job or task, regardless of where they were first acquired. Specific competencies, on the other hand, are applicable only in environment, which they are designed for. It means that leaving the environment leads to the devaluation of specific competencies, because they are not applicable in other companies or jobs. The existence of purely general or purely specific forms of competencies is relatively rare in real life. Moreover, drawing the line between general and specific competencies is made difficult by its dependence on institutional and structural conditions of the market, i.e. on the context (Becker, 1993).

Because of a dependence of generality / specificity (i.e. applicability) of competencies on the context, it is impossible to define any universal list of general competencies. This is illustrated by an existence of many approaches concerning general competencies, e.g. Generic skills, Key competencies, Employability skills, Essential skills, Core skills and others, whose similarity is not given only by used definitions, but also by the particular competencies included in the clusters (see Table 1.2 in Balcar, Homolová, Karásek et al., 2011 for their detailed description).

The list of general competencies used in this paper results from particular requirements occurring in job advertisements. Because the requirements in job advertisements differ in their level of aggregation, their classification was necessary. This process led to the following list of general competencies (in alphabetical order), which are discussed in this paper: Foreign languages and ICT competencies, corresponding 
to hard competencies, and Analytical and logical thinking, Cooperation and team work, Communication and presentation, Creativity, Customer orientation, Efficiency and achievement orientation, Flexibility, Independence, Life-long learning and self-development, Loyalty, Organizing, planning and leadership, Proactive approach and problem solving, Responsibility, reliability and diligence, Sale and negotiation, Strategic thinking, Stress resiliency, Work motivation, corresponding to soft competencies.

\section{Overview of Empiric Evidence on General Competencies in the Czech Republic}

Only slightly higher preferences of specific professional competencies (51.5-57.1\%) compared to general ones (42.9-48.5\%) were identified among Czech employers from various economic sectors (Burdová, Paterová, 2009; Kalousková, 2007; Kalousková, 2006; Kalousková, Št’astnová, Úlovcová, Vojtěch, 2004). A set of general competencies in stated studies cover both soft competencies and non-soft competencies. The soft competencies were identified as more important in comparison with non-soft competencies. ${ }^{1}$ Both employers (Burdová, Paterová, 2009; Kalousková, 2007; Kalousková, 2006; Kalousková, Št’astnová, Úlovcová, Vojtěch, 2004) and employment offices (Skácelová, Vojtěch, 2009; Burdová, Trhlíková, Vojtěch, 2007) report a positive correlation between the importance of general competencies (including soft competencies) and the educational attainment of an individual.

An identification of soft competencies with the highest productive potential represents the aim of many empirical studies, which differ in methodology approaches and their focus. The studies identify the soft competencies by questionnaire surveys realized in different sectors (e.g. Burdová, Paterová, 2009; Kalousková, 2007; Kalousková, 2006; Kalousková, Št’astnová, Úlovcová, Vojtěch, 2004; Karásek et al., 2004) or regions (e.g. Balcar, Filipová, Gottvald, Šimek, Šmajstrlová, 2008; Gavenda, 2006; Havlena, 2004), job advertisements analyses (e.g. Štastnová, Kalousková, Úlovcová, Vojtěch, 2008 and 2006) and interviews with representatives of private recruitment agencies (e.g. Štastnová, Kalousková, Úlovcová, Vojtěch, 2008 and 2006) or public employment offices (e.g. Skácelová, Vojtěch, 2009; Burdová, Trhlíková, Vojtěch, 2007). Moreover, the studies often distinguish requirements on soft competencies according to workers' educational attainment, which further increase an amount of provided information on soft competencies.

1 All above stated studies (Burdová, Paterová, 2009; Kalousková, 2007; Kalousková, 2006; Kalousková, Št’astnová, Úlovcová, Vojtěch, 2004) use unified set of 13 general competencies including 9 soft competencies and 4 non-soft competencies (ICT skills, language skills, literacy and numeracy). It can be assumed that equal importance of soft and non-soft competencies in the defined set of competencies leads to uniform distribution of the soft and non-soft competencies in the list of 13 competencies ordered by their importance for employer, i.e. approximately 2 of 4 non-soft competencies should be present among the 7 most important of 13 competencies. The analysis of the studies, which contain information on 12 categories of workers (these categories differ in educational attainment, sector, region, year), showed that in average only 1.4 non-soft competencies were present among the 7 most important competencies, i.e. $35,4 \%$ of non-soft competencies were present among $53.8 \%$ of the most important competencies. 
The 12 studies stated in the previous paragraph provide information on demand for soft competencies in 36 categories of workers (these categories differ in educational attainment, sector, region, used methodology and year). Despite different methodologies and sets of competencies applied in the studies it is possible to state that Responsibility, Communication and Life-long learning fell within the 3 most important competencies in at least $1 / 2$ of the 36 categories and Flexibility/adaptability, Cooperation, Independence and Problem solving in more than $1 / 5$ of categories.

4 of the 12 studies (Burdová, Paterová, 2009; Kalousková, 2007; Kalousková, 2006; Kalousková, Štastnová, Úlovcová, Vojtěch, 2004) provide information also on future demand for competencies. It is possible to conclude that Life-long learning, Flexibility/ adaptability and Exploring and orientation in information belong most often to the 3 competencies, whose importance will increase the most in the future. It is worth noting that the importance of foreign languages and ICT skills, i.e. non-soft competencies, will increase more than the importance of any soft competency.

\section{Data and Methodology}

The database mapping vacancies and employers' requirements on job applicants in the Czech Republic has been created for the purpose of this paper. It focused on vacancies advertised by 8,154 economic subjects with 10 or more employees at their web sites (job advertisements published at web sites of personal agencies were not taken into consideration because of a risk of duplicity of records), which represent $18.7 \%$ of employers of this size in the Czech Republic (only economic subjects, whose number of employees is known, were taken into consideration). ${ }^{2}$ The sample was created by random selection from all economic subjects employing 10 or more employees with own web site contained in "Albertina: Firm monitor CR DVD 4/2009" database. The sample is statistically representative according to prevailing sector of economic activity (NACE rev. 2), geographic structure (NUTS 3 level) and ownership of the economic subject. ${ }^{3}$ The bias of the sample regarding the number of employees is given by under-representation of employers with 10-19 employees and over-representation of employers with 50-500 employers, which can be given by different propensity to be presented through own web sites among employers of different size.

Data gathering was carried out in October and November 2009. It was found that $95.4 \%$ of the 8,154 economic subjects taken into consideration have active web sites, but only $25.4 \%$ (i.e. 2,074 subjects) use their web sites for advertising vacancies. Only $65.0 \%$ of economic subjects having special section for vacancies advertising at their web sites advertised some vacancies at the time of data gathering (i.e. 1,348 subjects). A total number of 3,822 job advertisements was recorded, i.e. 2.84 advertisements per

2 "Albertina: Firm monitor CR DVD 4/2009" database provides information on number of employees for $29.8 \%$ of economic subjects.

3 Information on sample structure is available from authors on request. 
subject actually advertising vacancies and 0.54 advertisements per subject with web sites used for advertising vacancies. The vast majority of the 3,822 job advertisements (91.4\%) were looking for one employee and the rest $(8.5 \%)$ wanted more than 1 employee ( $0.1 \%$ of advertisements did not specificity the number of required workers).

The analysis of data is divided into a descriptive and an econometric part. The descriptive part shows absolute and relative frequencies of examined competencies according to education attainment. The econometric analysis tests the hypothesis, whether mentioned general competencies are really generally demanded or their demand differs significantly in dependence on required education and firm characteristics such as NACE, firm size and ownership (occupation was not used as an additional explanatory variable since the sample is not statistically representative according to this characteristic). The hypothesis was tested for the most frequent soft competencies (Communication and presentation; Responsibility, reliability and diligence; Independence; Flexibility; Organizing, planning and leadership; Cooperation and team work; Efficiency and achievement orientation), English and ICT general skills. Advertisements demanding more than 1 employee were excluded from the econometric analysis. Probit regression analysis was used for this purpose because of binary outcome variable. Thus, the model calculates a predicted probability of requiring competencies based on predictors (required education, NACE, firm size and ownership). All regressions were tested for specification errors, collinearity, goodness-of-fit and influential observations by means of standardized Pearson and deviance residuals and leverage.

\section{Requirements on General Competencies of the Czech Labour Force}

It is interesting that $37.89 \%$ of advertisements did not specify level of educational attainment required for the vacancy advertised. It may be due to either real irrelevancy of educational attainment for work performance for some jobs or assumption of advertisers that only competent persons with proper level of education will apply for particular jobs. Unfortunately it is not possible to identify the reason for missing information on educational attainment in job advertisements on the basis of available data.

Table 1

Job Offers according to Minimal Educational Attainment

\begin{tabular}{|l|r|c|}
\hline \multirow{2}{*}{$\begin{array}{l}\text { Minimal educational attainment } \\
\text { required in job advertisements }\end{array}$} & \multicolumn{2}{|c|}{ Total } \\
\cline { 2 - 3 } No education & Frequency & Share (\%) \\
\hline Basic school & 5 & 0.13 \\
\hline Vocational school & 22 & 0.58 \\
\hline High school & 437 & 11.43 \\
\hline College & 1184 & 30.98 \\
\hline University & 31 & 0.81 \\
\hline N.A. & 695 & 18.18 \\
\hline Number of advertisements & 1448 & 37.89 \\
\hline
\end{tabular}

Source: Authors. 
The $62.11 \%$ of advertisements that specified minimal level of educational attainment necessary for job performance required most often graduation from high school $(30.98 \%)$ as a minimum level of education, university degree (18.18\%) and graduation from vocational school $(11.43 \%)$. Workers with no or only basic education are virtually discarded $(0.71 \%)$.

More than half of advertisements $(53.77 \%$ ) did not provide any information on required field of study. It suggests that either advertisers rely on self-sorting mechanism of job applicants, i.e. individuals will apply for the job only if they find their field of study relevant for advertised vacancy, or field of study does not represent primary sorting device, because general abilities of individuals, signalled by level of education, are more relevant for work performance than knowledge in certain field (with exception of some jobs, such as medical doctors, where requirements on field of study are given by regulations). Advertisements with specification of required field of study (46.23\%) demand most often knowledge in technical sciences (19.13\%), healthcare, medical and pharmaceutical sciences (13.16\%), which was given by special situation in health sector in autumn 2009 (see Footnote No. 4), and social sciences and services (10.91\%). It is worth noting that the demand on field of study differs significantly for particular levels of educational attainment (see Table 2).

Table 2

Job Offers according to Field of Education

\begin{tabular}{|l|c|c|c|c|c|}
\hline \multirow{2}{*}{ Field of education } & \multicolumn{2}{|c|}{ Total } & $\begin{array}{c}\text { Vocational } \\
\text { school }\end{array}$ & $\begin{array}{c}\text { High } \\
\text { school }\end{array}$ & University \\
\cline { 2 - 6 } & Frequency & Share (\%) & Share (\%) & Share (\%) & Share (\%) \\
\hline Natural sciences (KKOV 1) & 79 & 2.07 & 0.23 & 1.44 & 5.90 \\
\hline $\begin{array}{l}\text { Technical sciences } \\
\text { (KKOV 2-3) }\end{array}$ & 731 & 19.13 & 50.34 & 24.83 & 17.70 \\
\hline $\begin{array}{l}\text { Agro-forestry and vet. } \\
\text { sciences (KKOV 4) }\end{array}$ & 32 & 0.84 & 2.06 & 0.59 & 1.73 \\
\hline $\begin{array}{l}\text { Healthcare, medical and } \\
\text { phar. sc. (KKOV 5) }\end{array}$ & 503 & 13.16 & 0.46 & 10.90 & 29.06 \\
\hline $\begin{array}{l}\text { Social sciences and } \\
\text { services (KKOV 6-7) }\end{array}$ & 417 & 10.91 & 9.84 & 14.44 & 21.01 \\
\hline $\begin{array}{l}\text { Culture and art sciences } \\
\text { (KKOV 8) }\end{array}$ & 3 & 0.08 & 0.00 & 0.08 & 0.00 \\
\hline Military sciences (KKOV 9) & 2 & 0.05 & 0.00 & 0.00 & 0.14 \\
\hline N.A. & 2055 & 53.77 & 37.07 & 47.72 & 24.46 \\
\hline Total & 3822 & 100.00 & 100.00 & 100.00 & 100.00 \\
\hline Number of advertisements & & 3822 & 437 & 1184 & 695 \\
\hline
\end{tabular}

Source: Authors. 
Significant differences were identified also referring to economic sectors. Vacancies in services (NACE G-U) represented $77.3 \%$ of all advertisements, in mining and industry (NACE C-F) represented $22.0 \%$ of advertisements and in agriculture (NACE A-B) only $0.7 \%$ of advertisements. It is possible to add that vacancies were advertised most often (more than 100 job advertisements) in following sub-sectors: 504 advertisements in Hospital activities (NACE 861) 4359 advertisements in Non-specialised wholesale trade (NACE 469), 273 advertisements in Retail sale in non-specialised stores (NACE 471), 170 advertisements in Construction of residential and non-residential buildings (NACE 412), 109 advertisements in Retail sale of other goods in specialised stores (NACE 477), 104 advertisements in Administration of the State and the economic and social policy of the community (NACE 841) and 101 advertisements in Wholesale on a fee or contract basis (NACE 461).

Table 3

\section{Sector Distribution of Job Offers}

\begin{tabular}{|l|c|c|c|c|c|}
\hline \multirow{2}{*}{ Economic sector } & \multicolumn{2}{|c|}{ Total } & $\begin{array}{c}\text { Vocational } \\
\text { school }\end{array}$ & High school & University \\
\cline { 2 - 6 } & Frequency & Share (\%) & Share (\%) & Share (\%) & Share (\%) \\
\hline Agriculture (NACE A-B) & 27 & 0.70 & 0.68 & 0.42 & 0.00 \\
\hline $\begin{array}{l}\text { Mining and industry } \\
\text { (NACE C-F) }\end{array}$ & 838 & 21.93 & 37.99 & 26.18 & 15.25 \\
\hline Services (NACE G-U) & 2957 & 77.37 & 61.33 & 73.40 & 84.75 \\
\hline Total & 3822 & 100.00 & 100.00 & 100.00 & 100.00 \\
\hline $\begin{array}{l}\text { Number of } \\
\text { advertisements }\end{array}$ & \multicolumn{2}{|c|}{3822} & 437 & 1184 & 695 \\
\hline
\end{tabular}

Source: Authors.

There are, however, significant differences in requirements on qualification level among particular sectors. ${ }^{5}$ It can be said that the higher (lower) educational attainment is required, the higher share of advertisements in Services (Agriculture or Mining $\&$ industry) can be identified. It can be illustrated by $84.75 \%$ share of advertisements from Services sector in the case of individuals with university degree in comparison with the share in the case of individuals graduated vocational school, which is $61.33 \%$. The situation is opposite for Mining \& industry or even Agriculture.

4 Extremely high demand for medical professions, i.e. 504 advertised vacancies in hospital activities (13.2\% of all advertisements), was caused by specific form of protests of Czech physician in public health facilities in autumn 2009. Czech physicians wanted higher wages and threatened their mass exodus to Germany. Hospital reacted to this situation by looking for new employees, who could fill vacancies in case of real exodus of physicians from Czech health facilities.

5 Descriptions of differences depending on level of educational attainment are based on differences among vocational school graduates, high school graduates and university graduates. Other levels of educational attainment are not taken into account due to small number of relevant advertisements (see Table 1). 
Work experience, usually in relevant branch, was stated as a condition for hiring in $37.34 \%$ of advertisements and as an advantage in another $8.97 \%$ of advertisements. It seems that work experience is still important factor for employers, because it was stated in $46.31 \%$ of advertisements. Taking into consideration only advertisements requiring work experience, $39.83 \%$ of them (i.e. $18.45 \%$ of all advertisements) specified also requirement for length of work experience, whose average value was 3.13 years.

Table 4

Job Offers according to Requirement for Work Experience

\begin{tabular}{|l|c|c|c|c|c|}
\hline \multirow{2}{*}{ Work experience } & \multicolumn{2}{|c|}{ Total } & $\begin{array}{c}\text { Vocational } \\
\text { school }\end{array}$ & High school & University \\
\cline { 2 - 6 } & Frequency & Share (\%) & Share (\%) & Share (\%) & Share (\%) \\
\hline Condition for hiring & 1427 & 37.34 & 43.71 & 45.95 & 46.04 \\
\hline Advantage for hiring & 343 & 8.97 & 17.62 & 11.49 & 4.60 \\
\hline $\begin{array}{l}\text { Any requirement for } \\
\text { work experience }\end{array}$ & 1770 & 46.31 & 61.33 & 57.44 & 50.64 \\
\hline $\begin{array}{l}\text { Number of } \\
\text { advertisements }\end{array}$ & \multicolumn{2}{|c|}{3822} & 437 & 1184 & 695 \\
\hline
\end{tabular}

Source: Authors.

Interesting relationships between demanded work experience and requirements for educational attainment can be identified mainly if sector differences are taken into account. Focusing on work experience as a condition for hiring, it can be stated that its frequency in advertisements is slightly increasing with growing level of demanded educational attainment (43.71\% of advertisements for vocational school graduates and $46.04 \%$ of advertisements for university graduates). It is driven mainly by significant growth of frequency of requirements on work experience with level of educational attainment in Mining \& industry (40.96\% of advertisements for vocational school graduates, $57.10 \%$ of advertisements for high school graduates and $66.98 \%$ of advertisements for university graduates), whereas there is an opposite trend in Service sector, although its extent is extremely small (45.52\% of advertisements for vocational school graduates, $42.00 \%$ of advertisements for high school graduates and $42.28 \%$ of advertisements for university graduates). An importance of work experience as an advantage for hiring decrease with growing level of educational attainment (the decrease is slightly steeper in Mining \& industry), because the work experience is declared as an advantage in $17.62 \%$ of advertisements for vocational school graduates, but only in $4.60 \%$ of advertisements for university graduates.

One third of advertisements (33.28\%) requires knowledge of at least one foreign language. $80.83 \%$ of these advertisements (i.e. $26.90 \%$ of all advertisements) want English, which thus represents the language most in demand. The second most important language is German (31.13\% share on advertisements requiring foreign language and $10.36 \%$ share on all advertisements). However, it should be emphasized that $82.58 \%$ 
of advertisements that required German also had English as a requirement. It shows that the role of German as a primary foreign language is much weaker that numbers in Table 5 suggest. Other languages are requested only sporadically.

It should be mentioned that there is relatively high proportion of job advertisements that contain a requirement for foreign language without any further specification (16.20\% share on advertisements requiring foreign language and $5.39 \%$ share on all advertisements). One could assume that the requirement for competency for communication in foreign language does not result from any real need of an employer, because the real need is always connected with particular foreign language.

Table 5

Job Offers according to Requirement for Foreign Language

\begin{tabular}{|l|c|c|c|c|c|}
\hline \multirow{2}{*}{ Foreign language } & \multicolumn{2}{|c|}{ Total } & $\begin{array}{c}\text { Vocational } \\
\text { school }\end{array}$ & High school & University \\
\cline { 2 - 6 } & Frequency & Share (\%) & Share (\%) & Share (\%) & Share (\%) \\
\hline English & 1028 & 26.90 & 6.86 & 38.43 & 46.47 \\
\hline German & 396 & 10.36 & 3.66 & 14.36 & 17.27 \\
\hline Russian & 54 & 1.41 & 0.23 & 1.69 & 2.73 \\
\hline French & 27 & 0.71 & 0.00 & 0.68 & 1.58 \\
\hline Spanish & 12 & 0.31 & 0.00 & 0.25 & 0.86 \\
\hline Italian & 11 & 0.29 & 0.23 & 0.25 & 0.43 \\
\hline Not specified & 206 & 5.39 & 2.06 & 5.07 & 8.49 \\
\hline $\begin{array}{l}\text { Any requirement } \\
\text { for foreign language }\end{array}$ & 1272 & 33.28 & 10.53 & 44.26 & 56.83 \\
\hline $\begin{array}{l}\text { Number of } \\
\text { advertisements }\end{array}$ & \multicolumn{2}{|c|}{3822} & 437 & 1184 & 695 \\
\hline
\end{tabular}

Source: Authors.

Demand for language competencies is growing with the level of educational attainment (see row "Any requirement for language" in Table 5) and this pattern is valid for all identified languages. For instance, English is required in $6.86 \%$ of advertisements for vocational school graduates, $38.43 \%$ of advertisements for high school graduates and $46.47 \%$ of advertisements for university graduates. An inter-sector comparison brings very interesting findings, because it shows that English (and also German with exception of vocational education) is more often required in Mining \& industry than in Services ( $30.12 \%$ vs. $26.09 \%$ for English, $13.21 \%$ vs. $9.34 \%$ for German). It is worth noting that the difference in frequency of language requirements is more than double in the case of jobs for university graduates (English is required by $85.85 \%$ of advertisements in Mining \& industry and $39.39 \%$ of advertisements in Services, German is required by $34.91 \%$ and $14.09 \%$ of advertisements respectively). There are two potential explanations for this phenomenon: First, there is a significant lack of employees with 
language competencies in Mining \& industry and thus the requirements for them are advertised more often. Second, the high demand on language competencies in Services is declared, but the real demand (i.e. subsequent application of these competencies) is much lower. It corresponds with a high proportion of advertisements requiring language competencies without their specification, which reach $6.46 \%$ of advertisements in Services in comparison with $0.39 \%$ in Mining and industry.

As the results show, ICT skills are also very important for employers, because they are required by $39.90 \%$ of advertisements. The demand for ICT skills, however, differs according to required level of these skills. General ICT skills, i.e. ability to use general software such as MS Word, MS Excel etc., are stated in $89.65 \%$ of advertisements with requirement for ICT skills (35.77\% of all advertisements). Knowledge of specific software, such as SAP or AutoCAD etc., are wanted in $31.08 \%$ of advertisements with ICT skills requirement $(12.40 \%$ of all advertisements) and skills necessary for programmers are required in $10.95 \%$ requiring for ICT skills $(4.37 \%$ of all advertisements). It is surprising that general ICT skills are not mentioned in all advertisements that require ICT skills. It can be put down to the fact that employers legitimately assume that people with advanced ICT skills are able to manage basic ICT tasks, such as work with office software etc., and so they do not state requirement for lower level of ICT skills in advertisements explicitly.

Table 6

Job Offers according to Requirement for ICT Skills

\begin{tabular}{|l|c|c|c|c|c|}
\hline \multirow{2}{*}{ Level of ICT skills } & \multicolumn{2}{|c|}{ Total } & $\begin{array}{c}\text { Vocational } \\
\text { school }\end{array}$ & High school & University \\
\cline { 2 - 6 } & Frequency & Share (\%) & Share (\%) & Share (\%) & Share (\%) \\
\hline $\begin{array}{l}\text { General ICT skills (i.e. MS } \\
\text { Office, Internet) }\end{array}$ & 1367 & 35.77 & 18.76 & 53.72 & 45.04 \\
\hline $\begin{array}{l}\text { Specific ICT skills (i.e. SAP, } \\
\text { AutoCAD) }\end{array}$ & 474 & 12.40 & 1.14 & 17.82 & 18.56 \\
\hline $\begin{array}{l}\text { Programming languages, } \\
\text { databases }\end{array}$ & 167 & 4.37 & 0.23 & 4.14 & 4.17 \\
\hline Any requirement for ICT skills & 1525 & 39.90 & 19.45 & 58.95 & 50.79 \\
\hline Number of advertisements & \multicolumn{2}{|c|}{3822} & 437 & 1184 & 695 \\
\hline
\end{tabular}

Source: Authors.

Requirements for ICT skills were stated most often in advertisements requiring high school graduation $(58.71 \%$ of advertisements), i.e. 8.16 percentage points more than in the case of university graduates and 39.50 percentage points more than in the case of vocational school graduates. Difference in ICT skills requirements between high school graduates and university graduates are given by higher demand for knowledge of general software in the case of high school graduates, because the demand for knowledge of specific software and programming languages \& databases are practically 
identical. Differences between requirements on high school or university graduates and vocational school graduates are significant regardless of the type of ICT skills.

Table 7

Job Offers according to Requirement for Soft Competencies

\begin{tabular}{|c|c|c|c|c|c|}
\hline \multirow{2}{*}{ Soft competencies } & \multicolumn{2}{|c|}{ Total } & \multirow{2}{*}{$\begin{array}{c}\begin{array}{c}\text { Vocational } \\
\text { school }\end{array} \\
\text { Share (\%) }\end{array}$} & \multirow{2}{*}{$\begin{array}{c}\text { High school } \\
\text { Share (\%) }\end{array}$} & \multirow{2}{*}{$\begin{array}{l}\text { University } \\
\text { Share (\%) }\end{array}$} \\
\hline & Frequency & Share (\%) & & & \\
\hline $\begin{array}{l}\text { Communication and } \\
\text { presentation }\end{array}$ & 1266 & 33.12 & 14.19 & 47.97 & 34.68 \\
\hline $\begin{array}{l}\text { Responsibility, } \\
\text { reliability and diligence }\end{array}$ & 1053 & 27.55 & 37.99 & 36.49 & 21.58 \\
\hline Independence & 895 & 23.42 & 18.99 & 32.85 & 27.05 \\
\hline Flexibility & 776 & 20.30 & 24.94 & 32.09 & 13.81 \\
\hline $\begin{array}{l}\text { Cooperation and team } \\
\text { work }\end{array}$ & 478 & 12.51 & 6.18 & 13.68 & 21.15 \\
\hline $\begin{array}{l}\text { Efficiency and } \\
\text { achievement } \\
\text { orientation }\end{array}$ & 459 & 12.01 & 9.84 & 16.22 & 9.21 \\
\hline $\begin{array}{l}\text { Organizing, planning } \\
\text { and leadership }\end{array}$ & 456 & 11.93 & 4.81 & 21.03 & 15.11 \\
\hline $\begin{array}{l}\text { Sale and negotiation } \\
\text { skills }\end{array}$ & 390 & 10.20 & 3.43 & 19.76 & 6.47 \\
\hline $\begin{array}{l}\text { Life-long learning and } \\
\text { self-development }\end{array}$ & 348 & 9.11 & 8.70 & 12.33 & 8.49 \\
\hline $\begin{array}{l}\text { Proactive approach } \\
\text { and problem solving }\end{array}$ & 333 & 8.71 & 3.66 & 13.77 & 11.22 \\
\hline Customer orientation & 276 & 7.22 & 6.86 & 10.98 & 3.45 \\
\hline Work motivation & 238 & 6.23 & 1.60 & 8.53 & 9.64 \\
\hline $\begin{array}{l}\text { Analytical and logical } \\
\text { thinking }\end{array}$ & 212 & 5.55 & 0.69 & 7.35 & 11.37 \\
\hline Creativity & 170 & 4.45 & 2.29 & 6.59 & 4.17 \\
\hline Loyalty & 149 & 3.90 & 2.29 & 6.25 & 1.44 \\
\hline Stress resiliency & 148 & 3.87 & 1.37 & 7.18 & 2.30 \\
\hline Strategic thinking & 44 & 1.15 & 0.00 & 1.35 & 3.31 \\
\hline $\begin{array}{l}\text { Any requirement for } \\
\text { soft competency }\end{array}$ & 2337 & 61.15 & 62.93 & 74.92 & 65.32 \\
\hline $\begin{array}{l}\text { Number of } \\
\text { advertisements }\end{array}$ & 38 & & 437 & 1184 & 695 \\
\hline
\end{tabular}

Source: Authors.

Requirements for particular soft competencies became an integral part of job advertisements, because at least one soft competency is demanded in $61.15 \%$ of advertisements. Communication and presentation (33.12\% of advertisements), Responsibility, 
reliability and diligence (27.55\%), Independence (23.42\%), Flexibility (20.30\%) and Cooperation and team work (12.51\%) are most frequently demanded soft competencies. It corresponds closely to results of empirical studies from last decade (see Section 2 for comparison).

Requirements of soft competencies differ for various levels of educational attainment as well. At least one soft competency is demanded by $62.93-74.92 \%$ of advertisements depending on the level of educational attainment required. Similarities of and differences in requirements on soft competencies of individuals with various levels of educational attainment can be identified through comparison of the 5 most often demanded competencies. If the 5 competencies are compared for vocational school graduates, high school graduates and university graduates, it will show that Communication and presentation, Responsibility, reliability and diligence and Independence are demanded in all cases, although their rank among the 5 competencies differs. The 2 remaining competencies are even more interesting, because they describe specifics of demand for soft competencies of particular levels of educational attainment. It can be stated that Flexibility and Efficiency and achievement orientation in the case of vocational school graduates, Flexibility and Sale and negotiation skills in the case of high school graduates and Cooperation and team work and Organizing, planning and leadership in the case of university graduates can be found among the special requirements.

\section{Requirements on General Competencies in Dependence on Education, Sector, Firm Size and Ownership}

In this section, the hypothesis whether general competencies are required generally or their demand differs significantly depending on required education and firm characteristics such as NACE, firm size and ownership is tested.

There was an intention to test the hypothesis for English, general ICT skills and the 7 most demanded soft competencies (see Table 7). However, diagnostic tests of regression model for English revealed some problem, especially with the specification error which might indicate an omitted variable or problem with the function form, which led to exclusion of this model from the analysis. The model stability was ensured by checking for empty or small cells by developing crosstabs between categorical predictors and the outcome variables. That is why some categories of explanatory variables were excluded from the regressions and each regression contains different categories of variables. The categories that were included in regressions are stated in Table 8. Since all predictors of probit models are categorical, dummy variables technique was applied. Thus, the estimated coefficients (see Table 8) have to be interpreted in comparison with the reference group which is advertisements of the middle size (50-249 employees) private enterprises in manufacturing sector (NACE C) requiring workers with high school as minimal educational attainment suitable for given job. 
Table 8

Requirements of Competencies in Dependence on Education, Economic Sector and Firm's Ownership

\begin{tabular}{|c|c|c|c|c|c|c|c|c|}
\hline & 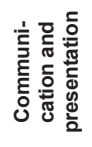 & 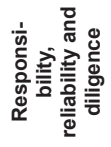 & 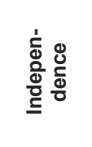 & $\begin{array}{l}\text { 름 } \\
\frac{\bar{a}}{x} \\
\frac{0}{4}\end{array}$ & 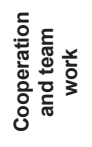 & 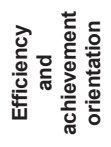 & 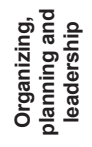 & 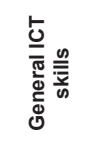 \\
\hline \multicolumn{9}{|c|}{ Education: High school as a reference } \\
\hline Vocational & $\begin{array}{c}-1.0255^{*} \\
(.0885)\end{array}$ & $\begin{array}{l}-.0677 \\
(.0786)\end{array}$ & $\begin{array}{l}-.5897^{*} \\
(.0864)\end{array}$ & $\begin{array}{l}-.4127^{*} \\
(.0839)\end{array}$ & $\begin{array}{l}-.3811^{*} \\
(.1161) \\
\end{array}$ & $\begin{array}{l}-.3470^{*} \\
(.1075)\end{array}$ & $\begin{array}{l}-.8765^{*} \\
(.1196)\end{array}$ & $\begin{array}{c}-1.0883^{*} \\
(.0854)\end{array}$ \\
\hline University & $\begin{array}{l}-.2267^{*} \\
(.0693)\end{array}$ & $\begin{array}{l}-.2158^{*} \\
(.0738)\end{array}$ & $\begin{array}{l}.0917 \\
(.0725)\end{array}$ & $\begin{array}{l}-.5166^{*} \\
(.0812)\end{array}$ & $\begin{array}{l}.4737^{*} \\
(.0816)\end{array}$ & $\begin{array}{l}-.1192 \\
(.0924)\end{array}$ & $\begin{array}{l}-.2220^{*} \\
(.0803)\end{array}$ & $\begin{array}{l}-.2680^{*} \\
(.0678)\end{array}$ \\
\hline N.A. & $\begin{array}{l}-.4890^{*} \\
(.0601)\end{array}$ & $\begin{array}{l}-.6137^{*} \\
(.0642)\end{array}$ & $\begin{array}{l}-.5375^{*} \\
(.0654)\end{array}$ & $\begin{array}{l}-.7055^{*} \\
(.0683)\end{array}$ & $\begin{array}{l}-.1741^{*} \\
(.0811)\end{array}$ & $\begin{array}{l}-.3805^{*} \\
(.0779)\end{array}$ & $\begin{array}{l}-.7256^{*} \\
(.0802)\end{array}$ & $\begin{array}{l}-.7778^{*} \\
(.0603)\end{array}$ \\
\hline \multicolumn{9}{|c|}{ Firm size: Medium enterprise (50-249 employees) as a reference } \\
\hline $\begin{array}{l}\text { Small enterprise } \\
\text { (10-49 employees) }\end{array}$ & $\begin{array}{c}.1047 \\
(.0613)\end{array}$ & $\begin{array}{l}.1450^{*} \\
(.0612)\end{array}$ & $\begin{array}{c}.0514 \\
(.0632)\end{array}$ & $\begin{array}{l}-.0261 \\
(.0654)\end{array}$ & $\begin{array}{l}.2067^{*} \\
(.0778)\end{array}$ & $\begin{array}{l}.3918^{*} \\
(.0735)\end{array}$ & $\begin{array}{c}.1497 \\
(.0805)\end{array}$ & $\begin{array}{l}-.0974 \\
(.0614)\end{array}$ \\
\hline $\begin{array}{l}\text { Large enterprise } \\
\text { (250+ employees) }\end{array}$ & $\begin{array}{l}.0364 \\
(.0699)\end{array}$ & $\begin{array}{l}-.1832^{*} \\
(.0710)\end{array}$ & $\begin{array}{l}-.0979 \\
(.0725)\end{array}$ & $\begin{array}{l}.0527 \\
(.0757)\end{array}$ & $\begin{array}{l}.1336 \\
(.0893)\end{array}$ & $\begin{array}{l}-.2423^{*} \\
(.0977)\end{array}$ & $\begin{array}{l}.2549^{*} \\
(.0859)\end{array}$ & $\begin{array}{l}-.0459 \\
(.0693)\end{array}$ \\
\hline \multicolumn{9}{|c|}{ NACE: Manufacturing (NACE C) as a reference } \\
\hline Construction (NACE F) & $\begin{array}{l}-.5350^{\star} \\
(.1186)\end{array}$ & $\begin{array}{l}-.2861^{*} \\
(.1135)\end{array}$ & $\begin{array}{l}-.4583^{*} \\
(.1219)\end{array}$ & $\begin{array}{l}-.0610 \\
(.1208)\end{array}$ & $\begin{array}{l}-.3437^{*} \\
(.1493) \\
\end{array}$ & $\begin{array}{l}-.2772 \\
(.1471)\end{array}$ & $\begin{array}{l}-.2582 \\
(.1507)\end{array}$ & $\begin{array}{l}-.4836^{*} \\
(.1167)\end{array}$ \\
\hline $\begin{array}{l}\text { Wholesale and retail trade } \\
\text { (NACE G) }\end{array}$ & $\begin{array}{c}.1055 \\
(.0752)\end{array}$ & $\begin{array}{c}.1278 \\
(.0754)\end{array}$ & $\begin{array}{c}.0219 \\
(.0778)\end{array}$ & $\begin{array}{l}.3290^{*} \\
(.0811)\end{array}$ & $\begin{array}{l}-.1901^{*} \\
(.0923)\end{array}$ & $\begin{array}{l}.2568^{*} \\
(.0939)\end{array}$ & $\begin{array}{l}-.0800 \\
(.0956)\end{array}$ & $\begin{array}{c}.1331 \\
(.0759)\end{array}$ \\
\hline $\begin{array}{l}\text { Transportation and storage } \\
\text { (NACE H) }\end{array}$ & $\begin{array}{l}-.5534^{*} \\
(.1787)\end{array}$ & $\begin{array}{l}.4380^{*} \\
(.1540)\end{array}$ & $\begin{array}{l}.4236^{*} \\
(.1570)\end{array}$ & $\begin{array}{l}.0946 \\
(.1761)\end{array}$ & & & $\begin{array}{c}.0210 \\
(.2100)\end{array}$ & $\begin{array}{l}-.1701 \\
(.1665)\end{array}$ \\
\hline $\begin{array}{l}\text { Information and } \\
\text { communication (NACE J) }\end{array}$ & $\begin{array}{l}.2952^{*} \\
(.1431)\end{array}$ & $\begin{array}{l}.0573 \\
(.1455)\end{array}$ & $\begin{array}{l}-.1210 \\
(.1513)\end{array}$ & $\begin{array}{l}.1071 \\
(.1596)\end{array}$ & $\begin{array}{l}.3381^{*} \\
(.1577)\end{array}$ & $\begin{array}{l}.5090^{*} \\
(.1579)\end{array}$ & $\begin{array}{l}.2026 \\
(.1686)\end{array}$ & $\begin{array}{l}.3146^{*} \\
(.1459)\end{array}$ \\
\hline $\begin{array}{l}\text { Financial and insurance } \\
\text { activities (NACE K) }\end{array}$ & $\begin{array}{l}.7304^{*} \\
(.1321)\end{array}$ & $\begin{array}{l}-.0112 \\
(.1262)\end{array}$ & $\begin{array}{c}.1028 \\
(.1249)\end{array}$ & $\begin{array}{l}-.1113 \\
(.1360)\end{array}$ & $\begin{array}{l}.3888^{*} \\
(.1333)\end{array}$ & $\begin{array}{c}.1351 \\
(.1560) \\
\end{array}$ & $\begin{array}{c}.0730 \\
(.1386) \\
\end{array}$ & $\begin{array}{l}-.3505^{*} \\
(.1239) \\
\end{array}$ \\
\hline $\begin{array}{l}\text { Real estate activities } \\
\text { (NACE L) }\end{array}$ & $\begin{array}{c}.0128 \\
(.1357)\end{array}$ & $\begin{array}{l}-.0040 \\
(.1364)\end{array}$ & $\begin{array}{l}-.0667 \\
(.1406)\end{array}$ & $\begin{array}{l}.1747 \\
(.1443)\end{array}$ & $\begin{array}{l}-.2792 \\
(.1759)\end{array}$ & $\begin{array}{l}.1586 \\
(.1633)\end{array}$ & $\begin{array}{l}.1000 \\
(.1658)\end{array}$ & $\begin{array}{l}.1106 \\
(.1365)\end{array}$ \\
\hline $\begin{array}{l}\text { Professional, scientific and } \\
\text { tech. activities (NACE M) }\end{array}$ & $\begin{array}{c}.0202 \\
(.0970)\end{array}$ & $\begin{array}{l}-.0684 \\
(.0976)\end{array}$ & $\begin{array}{c}.0277 \\
(.0990)\end{array}$ & $\begin{array}{l}.3940^{*} \\
(.1027)\end{array}$ & $\begin{array}{c}.0629 \\
(.1115)\end{array}$ & $\begin{array}{l}.0276 \\
(.1207)\end{array}$ & $\begin{array}{l}.0275 \\
(.1188)\end{array}$ & $\begin{array}{c}.0133 \\
(.0973) \\
\end{array}$ \\
\hline $\begin{array}{l}\text { Administrative and support } \\
\text { service activities (NACE N) }\end{array}$ & $\begin{array}{l}.2367 \\
(.1476)\end{array}$ & $\begin{array}{l}.4327^{*} \\
(.1452)\end{array}$ & $\begin{array}{l}.2184 \\
(.1503)\end{array}$ & $\begin{array}{l}.2450 \\
(.1603)\end{array}$ & & & $\begin{array}{l}.5100^{*} \\
(.1730)\end{array}$ & $\begin{array}{l}-.2158 \\
(.1585)\end{array}$ \\
\hline $\begin{array}{l}\text { Public administration and } \\
\text { defence (NACE O) }\end{array}$ & $\begin{array}{l}-.0780 \\
(.1643)\end{array}$ & $\begin{array}{l}-.1912 \\
(.1941)\end{array}$ & $\begin{array}{l}-.5497^{*} \\
(.1912)\end{array}$ & $\begin{array}{l}-.3423 \\
(.2234)\end{array}$ & $\begin{array}{l}-.4917^{*} \\
(.2282)\end{array}$ & $\begin{array}{l}-.0694 \\
(.3057)\end{array}$ & $\begin{array}{l}-.1962 \\
(.2031)\end{array}$ & $\begin{array}{l}.0038 \\
(.1628)\end{array}$ \\
\hline Education (NACE P) & $\begin{array}{l}-.5736^{*} \\
(.2036)\end{array}$ & & & & & & & \\
\hline $\begin{array}{l}\text { Human health and social } \\
\text { work activities (NACE Q) }\end{array}$ & $\begin{array}{c}-1.1662^{*} \\
(.1318)\end{array}$ & $\begin{array}{l}-.9904^{*} \\
(.1498)\end{array}$ & $\begin{array}{c}-1.1259^{*} \\
(.1483)\end{array}$ & $\begin{array}{c}-1.2370^{*} \\
(.1909)\end{array}$ & $\begin{array}{l}-.9426^{*} \\
(.1748)\end{array}$ & $\begin{array}{l}-.2354 \\
(.1709)\end{array}$ & $\begin{array}{l}-.8764^{*} \\
(.1718)\end{array}$ & $\begin{array}{l}-.8777^{*} \\
(.1210)\end{array}$ \\
\hline $\begin{array}{l}\text { Other service activities } \\
\text { (NACE S) }\end{array}$ & $\begin{array}{l}-.4714 \\
(.3202)\end{array}$ & & & & & & & $\begin{array}{l}-.4917 \\
(.3206)\end{array}$ \\
\hline \multicolumn{9}{|c|}{ Ownership: Private as a reference } \\
\hline Foreign & $\begin{array}{l}.1349 \\
(.0690)\end{array}$ & $\begin{array}{l}.1238 \\
(.0690)\end{array}$ & $\begin{array}{l}.0862 \\
(.0701)\end{array}$ & $\begin{array}{l}.0247 \\
(.0723)\end{array}$ & $\begin{array}{l}.1341 \\
(.0830)\end{array}$ & $\begin{array}{l}-.2765^{*} \\
(.0917)\end{array}$ & $\begin{array}{l}.1497 \\
(.0826)\end{array}$ & $\begin{array}{l}.2128^{*} \\
(.0693)\end{array}$ \\
\hline Municipal & $\begin{array}{l}-.0477 \\
(.1329)\end{array}$ & $\begin{array}{l}-.3808^{*} \\
(.1727)\end{array}$ & $\begin{array}{l}-.0953 \\
(.1599)\end{array}$ & $\begin{array}{l}-.0386 \\
(.1996)\end{array}$ & $\begin{array}{l}-.0305 \\
(.1858)\end{array}$ & $\begin{array}{l}-.4244^{*} \\
(.2047)\end{array}$ & $\begin{array}{l}.3608^{*} \\
(.1733)\end{array}$ & $\begin{array}{l}.0475 \\
(.1224)\end{array}$ \\
\hline State & $\begin{array}{l}.3510^{*} \\
(.1573)\end{array}$ & $\begin{array}{l}.0755 \\
(.1859)\end{array}$ & $\begin{array}{c}-.0972 \\
(.1838)\end{array}$ & $\begin{array}{l}-.2836 \\
(.2191)\end{array}$ & $\begin{array}{l}-.1024 \\
(.2257)\end{array}$ & & $\begin{array}{l}.1773 \\
(.1932)\end{array}$ & $\begin{array}{l}.9393^{*} \\
(.1564)\end{array}$ \\
\hline International & & & & & $\begin{array}{l}.5928^{*} \\
(.2725)\end{array}$ & & & $\begin{array}{l}.6246^{*} \\
(.2503)\end{array}$ \\
\hline Cons & $\begin{array}{c}-.0311 \\
(.0778)\end{array}$ & $\begin{array}{l}-.2286^{*} \\
(.0787) \\
\end{array}$ & $\begin{array}{l}-.2741^{*} \\
(.0803)\end{array}$ & $\begin{array}{l}-.4797^{*} \\
(.0840)\end{array}$ & $\begin{array}{c}-1.1122^{*} \\
(.0969)\end{array}$ & $\begin{array}{c}-1.0260^{*} \\
(.0995)\end{array}$ & $\begin{array}{l}-.9201^{*} \\
(.0958)\end{array}$ & $\begin{array}{l}.2410^{*} \\
(.0780)\end{array}$ \\
\hline Observations & 3266 & 3209 & 3180 & 3181 & 3032 & 2855 & 3174 & 3234 \\
\hline LR chi2 & $585.72^{*}$ & $423.22^{*}$ & $361.85^{\star}$ & $383.33^{*}$ & $224.66^{*}$ & $212.94^{*}$ & $215.56^{*}$ & $569.81^{*}$ \\
\hline
\end{tabular}

Source: Authors. 
The minimal educational attainment was statistically significant predictor of demand for nearly all analysed general competencies. As was expected, requirements on soft and general ICT skills were present more often in job advertisements demanding high school graduation as a minimal educational attainment (reference group) in comparison with ones requiring graduation from vocational school. On the other hand, it was surprising that the soft and general ICT skills requirements were present rarer in job advertisements demanding high school graduation in comparison with advertisements demanding university degree, with an exception of cooperation and team work, where the probability of demanding them is 0.43 times higher in advertisements requiring university degree (moreover, there are no statistically significant differences in the case of independence and efficiency). Only employers' expectations that university graduates already have all these competencies, and therefore there is no need to advertise them, represent possible explanation of this result.

Frequency of requirements on soft competencies is affected also by firm size in the case of some soft competencies. Small enterprises demand Responsibility, reliability and diligence, Efficiency and achievement orientation, and Cooperation and team work more often than middle size and large sizes companies (in case of first two soft competencies the frequency of requirements decrease with company size). This conclusion, however, corresponds with small firms' characteristics, because their relatively low economic power put pressure on high productivity of labour. Organizing, planning and leadership are, on the other hand, more often demanded by large firms, whose formal structure creates higher need for competencies connected with leading or managing activities.

Manufacturing, i.e. reference sector, is a very heterogeneous but relatively demanding economic sector. Therefore, identification of sectors with statistically different demand for particular competencies can be very interesting. The results confirmed that there are both sectors with significantly higher requirements on general competencies (e.g. NACE J or NACE N) and sectors with significantly lower demand for analysed competencies (e.g. NACE F, NACE O or NACE Q).

There are also some statistically significant differences in frequency of requirements on soft competencies and general ICT skills according to the ownership of the firms, but there is no obvious explanation for e.g. lower demand for efficiency and achievement orientation in enterprises owned by foreign capital or by municipalities. Authors could not find any theory that would support or explain these results.

To sum up, all regressions proved that the requirements for tested competencies differ significantly according to education required, firm size, economic sector and ownership.

\section{Conclusions}

This paper focuses on the identification and description of general (i.e. broadly applicable) competencies required on the Czech labour market. The descriptive analysis 
is replenished with econometric analysis testing hypothesis whether examined demand for general competencies is really general or it differs significantly in dependence on required education and firm characteristics such as NACE and ownership.

The descriptive part of the analysis shows that $33.28 \%$ of advertisements require knowledge of at least one foreign language. $80.83 \%$ of these advertisements want English, which thus represents the language most in demand. Data also indicates that demand for language competencies is growing with the level of educational attainment and this pattern is valid for all identified languages. ICT skills are also very important for employers, as they are required by $39.90 \%$ of advertisements.

Referring to soft competencies, at least one soft competency is a prerequisite in $61.15 \%$ of advertisements. Communication and presentation, Responsibility, reliability and diligence, Independence, Flexibility and Cooperation and team work are the most frequently demanded soft competencies (which corresponds to the results of the recent empirical studies) but their demand differs on the basis of required education. Communication and presentation, Responsibility, reliability and diligence and Independence are demanded in all educational levels although their rank of importance differs. On the contrary, Flexibility and Efficiency and achievement orientation is required mainly together with vocational level, Flexibility and Sale and negotiation skills with high school level and Cooperation and team work and Organizing, planning and leadership with university level.

The econometric part of the analysis proved our hypothesis that so-called general competencies such as ICT skills and soft competencies are not generally requested but their demand significantly differs according to the education required and in some cases also according to NACE, firm size and ownership of the firms.

\section{References}

Balcar, J., Homolová, E., Karásek, Z. et al. (2011), “Transferable Competences across Economic Sectors: Role and Importance for Employment at European Level." Luxembourg: Publications Office of the European Union. Retrieved March 1, 2012, from http://ec.europa.eu/social/BlobServlet ?docld=7124\&langld=en.

Balcar, J., Filipová, L., Gottvald, J., Šimek, M., Šmajstrlová, S. (2008), Uplatnitelnost absolventů škol v podnicích a institucích Moravskoslezského kraje. [CD-ROM], Ostrava: VŠB-TUO. Retrieved March 1, 2012, from http://resa.rza.cz/www/file.php?id=72.

Becker, G. S. (1993), Human Capital: A Theoretical and Empirical Analysis with Special Reference to Education. Chicago: The University of Chicago Press.

Belz, H., Siegrist, M. (2001), Klíčové kompetence a jejich rozvíjení: východiska, metody, cvičení a hry. Praha: Portál.

Burdová, J., Paterová, P. (2009), "Šetření potřeb zaměstnavatelů a připravenosti absolventů v zemědělské sféře." Ministerstvo školství, mládeže a tělovýchovy, Praha. Retrieved March 1, 2012, from http://www.infoabsolvent.cz/TematickyKatalog/Download.aspx?soubor=F-9.0.40-XX_Potreby_ zamestnavatelu_a_pripravenost_absolventu_skol_-_setreni_v_zemedelske_sfere.pdf.

Burdová, J., Trhlíková, J., Vojtěch, J. (2007), "Názory pracovníků úřadů práce na uplatnění absolventů škol - 2006." Ministerstvo školství, mládeže a tělovýchovy, Praha. Retrieved March 1, 2012, from http://www.nuov.cz/uploads/Vzdelavani_a_TP/nazory_UP_06.pdf. 
CEDEFOP (2002), Training and Learning for Competence. Luxembourg: Office for Official Publications of the European Communities.

Cripe, E. J., Mansfield, R. S. (2002), The Value-added Employee: 31 Skills to Make Yourself Irresistable to Any Company. Woburn: Butterworth-Heinemann.

European Commission (2008), The European Qualifications Framework for Lifelong Learning (EQF), Luxembourg: Office for Official Publications of the European Communities.

European Commission (2007), The Key Competences for Lifelong Learning - A European Framework. Luxembourg: Office for Official Publications of the European Communities. Retrieved March 1, 2012, from http://ec.europa.eu/dgs/education_culture/publ/pdf/l-learning/keycomp_en.pdf.

Gavenda, M. (2006), “Průzkum mezi podniky v Moravskoslezském kraji 2006.” Report, RPIC-ViP, Ostrava. Retrieved March 1, 2012, from http://resa.rza.cz/www/file.php?id=30.

Havlena, J. (2004), “Kompetenční model MS kraje: Anketa mezi velkými zaměstnavateli.” Report, RPIC-ViP, Ostrava. Retrieved March 1, 2012, from http://rzasystem.rza.cz/file.php?filelD=32.

Kalousková, P. (2006), "Potřeby zaměstnavatelů a připravenosti absolventů škol - šetření v terciární sféře." Ministerstvo školství, mládeže a tělovýchovy, Praha. Retrieved March 1, 2012, from http:// www.infoabsolvent.cz/TematickyKatalog/Download.aspx?soubor=Potreby_zamestnavatelutercialni_sfera-2006.pdf

Kalousková, P. (2007), "Potřeby zaměstnavatelů a připravenost absolventů škol - šetření v kvartérním sektoru." Ministerstvo školství, mládeže a tělovýchovy, Praha. Retrieved March 1, 2012, from http:// www.infoabsolvent.cz/TematickyKatalog/Download.aspx?soubor=Potreby\%20zamestnavatelu\%20 kvarter\%2007.pdf.

Kalousková, P., Št’astnová, P., Úlovcová, H., Vojtěch, J. (2004), "Potřeby zaměstnavatelů a prípravenost absolventů pro vstup na trh práce - 2004." Ministerstvo školství, mládeže a tělovýchovy, Praha. Retrieved March 1, 2012, from http://www.infoabsolvent.cz/TematickyKatalog/ Download.aspx?soubor=Potreby_zamestnavatelu-2004.pdf.

Karásek, Z. et al. (2004), "Profesní struktura ve strojírenském oboru v Moravskoslezském kraji." Report, RPIC, Ostrava. Retrieved March 1, 2012, from http://rzasystem.rza.cz/file.php?fileID=34.

Kessler, R. (2006), Competency-Based Interviews. Franklin Lakes: Career Press.

Kessler, R., Strasbourg, L. A. (2005), Competency-Based Resumes. Franklin Lakes: Career Press.

Schultz, T. W. (1961), "Investment in Human Capital." The American Economic Review, Vol. 51, No. 1, pp. 1-17.

Skácelová, P., Vojtěch, J. (2009), “Názory pracovníků úřadů práce na uplatnění absolventů škol v období ekonomické krize." Ministerstvo školství, mládeže a tělovýchovy, Praha. Retrieved March 1, 2012, from http://www.nuov.cz/uploads/Vzdelavani_a_TP/Nazory_pracovnikuUP2009.pdf.

Spencer, L. M., Spencer, S. M. (2008), Competence at Work-Models for Superior Performance. New York: John Wiley \& Sons, Inc.

Št’astnová, P., Kalousková, P., Úlovcová, H., Vojtěch, J. (2006), "Potřeby zaměstnavatelů z pohledu analýzy inzertní nabídky zaměstnání a názorů pracovníků personálních agentur (2006)." Ministerstvo školství, mládeže a tělovýchovy, Praha. Retrieved March 1, 2012, from http://www.infoabsolvent.cz/TematickyKatalog/Download.aspx?soubor=Potreby_zamestnavateluanalyza_inzerce-2006.pdf.

Štastnová, P., Kalousková, P., Úlovcová, H., Vojtěch, J. (2008), "Potřeby zaměstnavatelů z pohledu analýzy inzertní nabídky zaměstnání a názorů pracovníků personálních agentur (2007-08)." Ministerstvo školství, mládeže a tělovýchovy, Praha. Retrieved March 1, 2012, from http://www.infoabsolvent.cz/TematickyKatalog/Download.aspx?soubor=F-9.0.23-Ka_Potreby_ zamestnavatelu_z_pohledu_analyzy_inzertni_nabidky_zamestnani_a_nazoru_pracovniku_ personalnich_agentur_(2007-08).pdf.

Woodruffe, Ch. (1992), "What Is Meant by Competency?" In Boam, R., Sparrow, P., eds., Designing and Achieving Competency? London: McGraw-Hill, pp. 16-30. 